\title{
Indentification of a Tunable Site in Bryostatin Analogs: C20 Bryologs through Late Stage
} Diversification

\author{
Paul A. Wender, Jeremy L. Baryza
}

General Methods. Air- and moisture-sensitive reactions were carried out in oven-dried glassware sealed with rubber septa under a positive pressure of dry nitrogen or argon from a manifold or balloon, unless otherwise indicated. Similarly sensitive liquids and solutions were transferred via syringe or stainless steel cannula. Reactions were stirred using Teflon-coated magnetic stir bars. Organic solutions were concentrated using a Buchi rotary evaporator with a teflon seal vacuum pump. Analytical TLC was performed with $0.25 \mathrm{~mm}$ silica gel $60 \mathrm{~F}$ plates with $254 \mathrm{~nm}$ fluorescent indicator from Merck. Plates were visualized by ultraviolet light and treatment with acidic p-anisaldehyde stain followed by gentle heating. Chromatographic purification of products was accomplished by flash chromatography, as described by Still and co-workers, ${ }^{1}$ unless otherwise indicated. Silica gel 60, 230-400 mesh was purchased from EM.

NMR spectra were measured on a Mercury $400\left({ }^{1} \mathrm{H}\right.$ at $400 \mathrm{MHz},{ }^{13} \mathrm{C}$ at $\left.100 \mathrm{MHz}\right)$, Varian INOVA $500\left({ }^{1} \mathrm{H}\right.$ at $500 \mathrm{MHz},{ }^{13} \mathrm{C}$ at $\left.125 \mathrm{MHz}\right)$, or Varian INOVA $600\left({ }^{1} \mathrm{H}\right.$ at $600 \mathrm{MHz},{ }^{13} \mathrm{C}$ at $\left.150 \mathrm{MHz}\right)$ magnetic resonance spectrometer. Data for ${ }^{1} \mathrm{H}$ NMR spectra are reported as follows: chemical shift $(\delta \mathrm{ppm})$, integration, multiplicity $(\mathrm{s}=$ singlet, brs $=$ broad singlet, $\mathrm{d}=$ doublet, brd $=$ broad doublet, $\mathrm{t}=$ triplet, $\mathrm{q}=$ quartet, $\mathrm{dd}=$ doublet of doublets, $\mathrm{dt}=$ doublet of triplets, $\mathrm{ddd}=$ doublet of doublet of doublets, $\mathrm{dddd}=$ doublet of doublet of doublet of doublets, $\mathrm{ddt}=$ doublet of doublet of triplets, $\mathrm{m}=$ multiplet), coupling constant $(\mathrm{Hz})$. Data for ${ }^{13} \mathrm{C}$ are reported in terms of chemical shift relative to residual solvent peak. Infrared spectra were recorded on a Perkin-Elmer 1600 Series Fourier transform spectrometer (FTIR) and are reported in wavenumbers $\left(\mathrm{cm}^{-1}\right)$. High resolution mass spectra (HRMS) were recorded at the High Resolution Mass Spectrometry Facility, University of California at Riverside, at the Mass Spectrometry Facility, University of California at San Francisco, or at the PAN Facility, Stanford University. Purity is documented via high field ${ }^{1} \mathrm{H}$ NMR spectra showing at most only trace peaks not attributable to the assigned structure.

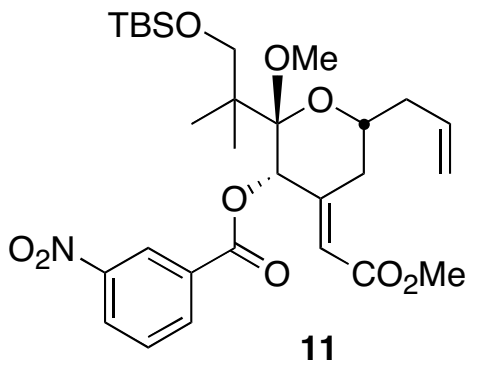

To a solution of $\mathbf{1 0}(175 \mathrm{mg}, 0.41 \mathrm{mmol})$ in $\mathrm{MeOH}(4 \mathrm{~mL})$ was added $\mathrm{CeCl}_{3} \cdot 7 \mathrm{H}_{2} \mathrm{O}(78 \mathrm{mg}, 0.21 \mathrm{mmol})$ and the mixture was stirred until homogenous then cooled in a $-30^{\circ} \mathrm{C}$ acetone bath. To this yellow solution was added $\mathrm{NaBH}_{4}(31 \mathrm{mg}, 0.82 \mathrm{mmol})$. The reaction quickly became colorless and was filtered through a plug of silica with 3:1 pet. ether:EtOAc as an eluant. Fractions containing product were poured into a separatory funnel and washed with water (2x) and brine (1x). The resulting organic layer was dried over $\mathrm{Na}_{2} \mathrm{SO}_{4}$, filtered and concentrated in vacuo to a clear oil that was used directly.

The oil from the previous step was dissolved in $\mathrm{CH}_{2} \mathrm{Cl}_{2}(10 \mathrm{~mL})$ and to the resulting solution was added DMAP (75 mg, $0.61 \mathrm{mmol}$ ) followed by 3-nitrobenzoic acid (102 mg, $0.61 \mathrm{mmol})$ and DIC (95 $\mu \mathrm{L}, 0.61$ mmol). The resulting mixture was stirred at $\mathrm{rt}$ overnight under $\mathrm{N}_{2}$. The reaction was then diluted with $\mathrm{CH}_{2} \mathrm{Cl}_{2}(10 \mathrm{~mL})$ and washed with satd. aq. $\mathrm{NaHCO}_{3}(10 \mathrm{~mL})$ and water $(10 \mathrm{~mL})$. The organic layer was collected and the aq. layer was extracted once with $\mathrm{CH}_{2} \mathrm{Cl}_{2}(10 \mathrm{~mL})$. The organic layers were combined, dried over $\mathrm{Na}_{2} \mathrm{SO}_{4}$, and concentrated in vacuo to a clear oil which was purified by flash chromatography (silica, 19:1 $\rightarrow$ 9:1 pentane:EtOAc) to yield $176 \mathrm{mg}(74 \%)$ of a clear oil.

$\mathbf{R}_{f}: 0.32$ (silica, 9:1 pentane:EtOAc) - one spot UV and $p$-anisaldehyde

${ }^{1}$ H NMR: $\left(\mathrm{CDCl}_{3}, 500 \mathrm{MHz}\right) \delta$ 8.88-8.86 $(1 \mathrm{H}, \mathrm{m}), 8.47-8.43(1 \mathrm{H}, \mathrm{m}), 8.37-8.34(1 \mathrm{H}, \mathrm{m})$, 7.71-7.66 $(1 \mathrm{H}$, m), 6.06-5.98 $(2 \mathrm{H}, \mathrm{m}), 5.69(1 \mathrm{H}, \mathrm{s}), 5.23-5.16(2 \mathrm{H}, \mathrm{m}), 3.95-3.88(1 \mathrm{H}, \mathrm{m}), 3.69(3 \mathrm{H}, \mathrm{s}), 3.61(1 \mathrm{H}, \mathrm{d}, J$

\footnotetext{
${ }^{1}$ Still, W.C.; Kahn, M.; Mitra, A. J. Org. Chem., 1978, 43, 2923.
} 
= 9.5 Hz), $3.57(1 \mathrm{H}, \mathrm{d}, J=2.7 \mathrm{~Hz}), 3.52(1 \mathrm{H}, \mathrm{d}, J=9.5 \mathrm{~Hz}), 3.39(3 \mathrm{H}, \mathrm{s}), 2.53-2.34(3 \mathrm{H}, \mathrm{m}), 1.08(3 \mathrm{H}$, s), $1.02(3 \mathrm{H}, \mathrm{s}), 0.82(9 \mathrm{H}, \mathrm{s}),-0.06(3 \mathrm{H}, \mathrm{s}),-0.12(3 \mathrm{H}, \mathrm{s}) \mathrm{ppm}$.

${ }^{13}$ C NMR: $\left(\mathrm{CDCl}_{3}, 100 \mathrm{MHz}\right) \delta 166.4,162.4,151.5,148.3,135.3,133.5,131.5,129.8,127.7,124.7,118.4$, 118.1, 103.0, 74.4, 71.2, 67.6, 51.7, 51.2, 46.6, 39.9, 30.7, 25.8, 21.1, 21.0, 18.3, -5.7 ppm.

IR: (thin film) 3084, 2953, 2856, 1723, 1667, 1618, 1537, 1436, 1352, 1127, 1072, 1041, 1004, $915 \mathrm{~cm}^{-1}$.

ES-MS: $m / z=600.2\left(\mathrm{M}+\mathrm{Na}^{+}\right)$

$[\alpha]_{\mathrm{D}}:-34.6^{\circ}\left(c=1.35, \mathrm{CH}_{2} \mathrm{Cl}_{2}\right)$

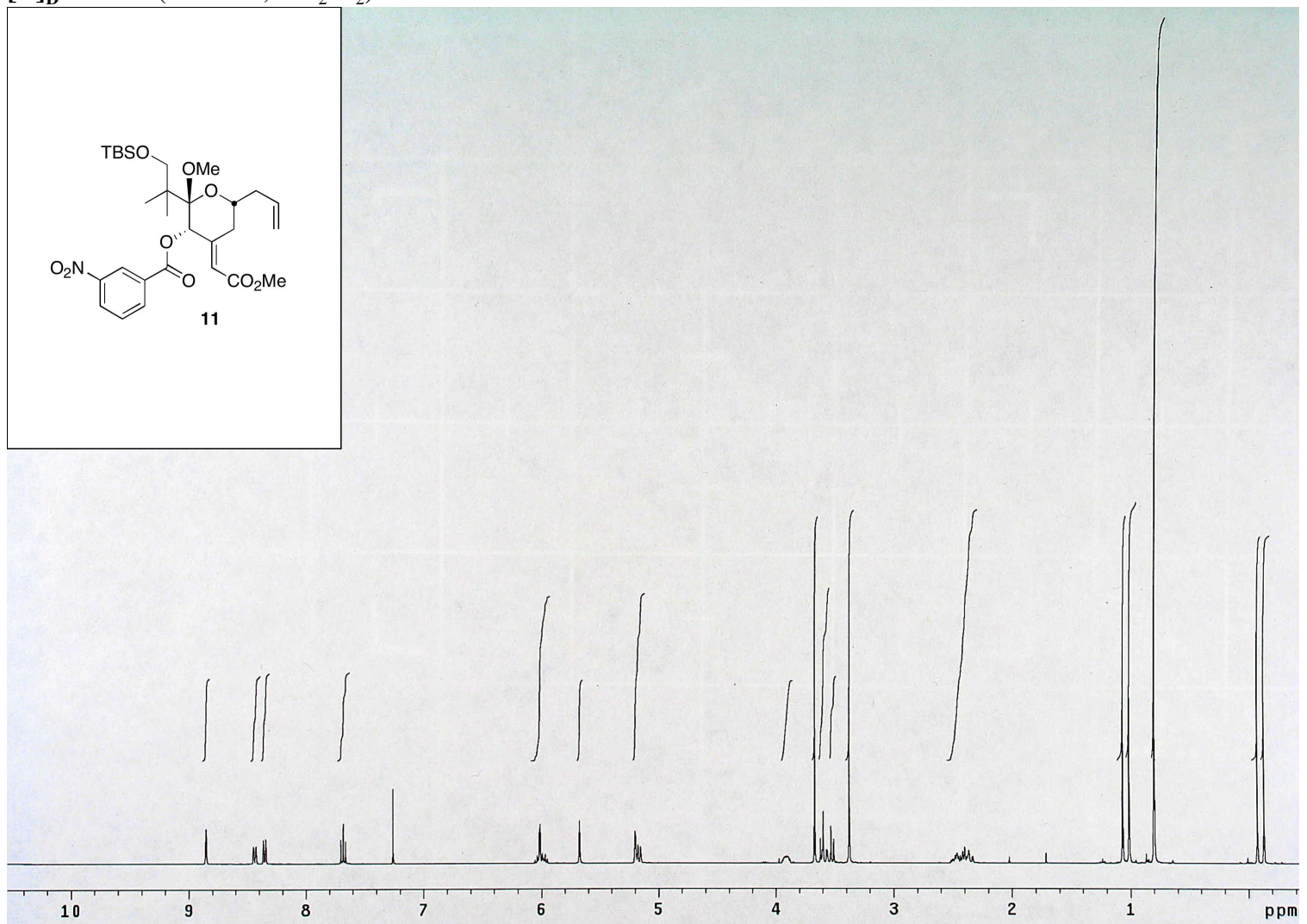




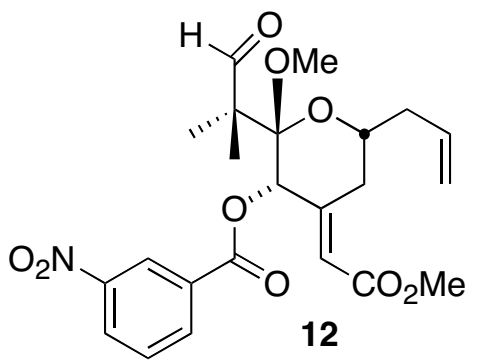

A solution of $11(1.94 \mathrm{~g}, 3.36 \mathrm{mmol})$ in THF $(80 \mathrm{~mL})$ was divided in two and each half stirred under a stream of $\mathrm{N}_{2}$ in a polypropylene vial. To each vial was added THF (20 mL) and $3 \mathrm{HF} \cdot \mathrm{NEt}_{3}(4 \mathrm{~mL}$ to each). The vials were capped and the contents stirred at $\mathrm{rt}$ for 3 days. The reaction mixtures were combined and poured into satd. aq. $\mathrm{NaHCO}_{3}(200 \mathrm{~mL})$ and the resulting mixture was extracted with EtOAc $(3 \times 70 \mathrm{~mL})$. The combined organic layers were dried over $\mathrm{Na}_{2} \mathrm{SO}_{4}$, concentrated in vacuo and the residue purified by flash chromatography (silica, 2:1 pentane:EtOAc) to yield $900 \mathrm{mg}$ of a clear oil.

The oil was dissolved in $\mathrm{CH}_{2} \mathrm{Cl}_{2}(20 \mathrm{~mL})$ and to the solution was added $\mathrm{NaHCO}_{3}(185 \mathrm{mg}, 2.2 \mathrm{mmol})$ and Dess-martin periodinane $(904 \mathrm{mg}, 2.13 \mathrm{mmol})$. The resulting mixture was stirred at $\mathrm{rt}$ for $45 \mathrm{~min}$ and then 1:1 satd. aq. $\mathrm{NaHCO}_{3}$ :satd. aq. $\mathrm{Na}_{2} \mathrm{~S}_{2} \mathrm{O}_{3}(20 \mathrm{~mL})$ was added. The resulting mixture was stirred until both phases were homogenous $(2 \mathrm{~min})$. The organic layer was collected and the aq. layer extracted with $\mathrm{CH}_{2} \mathrm{Cl}_{2}$ $(2 \times 10 \mathrm{~mL})$. The combined organic layers were dried over $\mathrm{Na}_{2} \mathrm{SO}_{4}$ and concentrated in vacuo. The resulting residue was purified by flash chromatography (silica, 4:1 pentane:EtOAc) to yield $759 \mathrm{mg}(50 \%)$ of a clear oil.

$\mathbf{R}_{f}: 0.46$ (silica, 4:1 pentane:EtOAc) - one spot UV and $p$-anisaldehyde

${ }^{1}$ H NMR: $\left(\mathrm{CDCl}_{3}, 500 \mathrm{MHz}\right) \delta 9.84(1 \mathrm{H}, \mathrm{s}), 8.55-8.52(1 \mathrm{H}, \mathrm{m}), 8.46-8.42(1 \mathrm{H}, \mathrm{m}), 8.24-8.20(1 \mathrm{H}, \mathrm{m})$, 7.70-7.65 (1 H, m), 6.05 (1 H, d, $J=1.7 \mathrm{~Hz}), 6.05-5.96(1 \mathrm{H}, \mathrm{m}), 5.51(1 \mathrm{H}, \mathrm{s}), 5.27-5.21(2 \mathrm{H}, \mathrm{m}), 3.96-$ $3.90(1 \mathrm{H}, \mathrm{m}), 3.73-3.67(1 \mathrm{H}, \mathrm{m}), 3.70(3 \mathrm{H}, \mathrm{s}), 3.46(3 \mathrm{H}, \mathrm{s}), 2.58-2.45(2 \mathrm{H}, \mathrm{m}), 2.33$ (1 H, ddd, $J=15.0$, 11.6, $2.0 \mathrm{~Hz}), 1.22(3 \mathrm{H}, \mathrm{s}), 1.07(3 \mathrm{H}, \mathrm{s}) \mathrm{ppm}$.

${ }^{13}$ C NMR: $\left(\mathrm{CDCl}_{3}, 100 \mathrm{MHz}\right) \delta$ 202.3, 166.1, 162.3, 149.5, 148.2, 135.5, 133.1, 130.5, 129.8, 127.9, 125.0, 120.1, 118.6, 102.1, 72.8, 71.8, 54.1, 51.5, 51.3, 39.8, 30.4, 18.9, 16.4 ppm.

IR: (thin film) 3084, 2980, 2950, 2838, 1721, 1669, 1617, 1537, 1437, 1352, 1256, 1123, 1069, 1046,987 $\mathrm{cm}^{-1}$.

HRMS: $m / z=390.1195\left(\mathrm{M}^{+}-\mathrm{OHCC}\left(\mathrm{CH}_{3}\right)_{2}\right)$. Calcd. For $\mathrm{C}_{19} \mathrm{H}_{20} \mathrm{NO}_{8} 390.1189$.

$[\alpha]_{\mathrm{D}}:-5.6^{\circ}\left(c=3.5, \mathrm{CDCl}_{3}\right)$ 


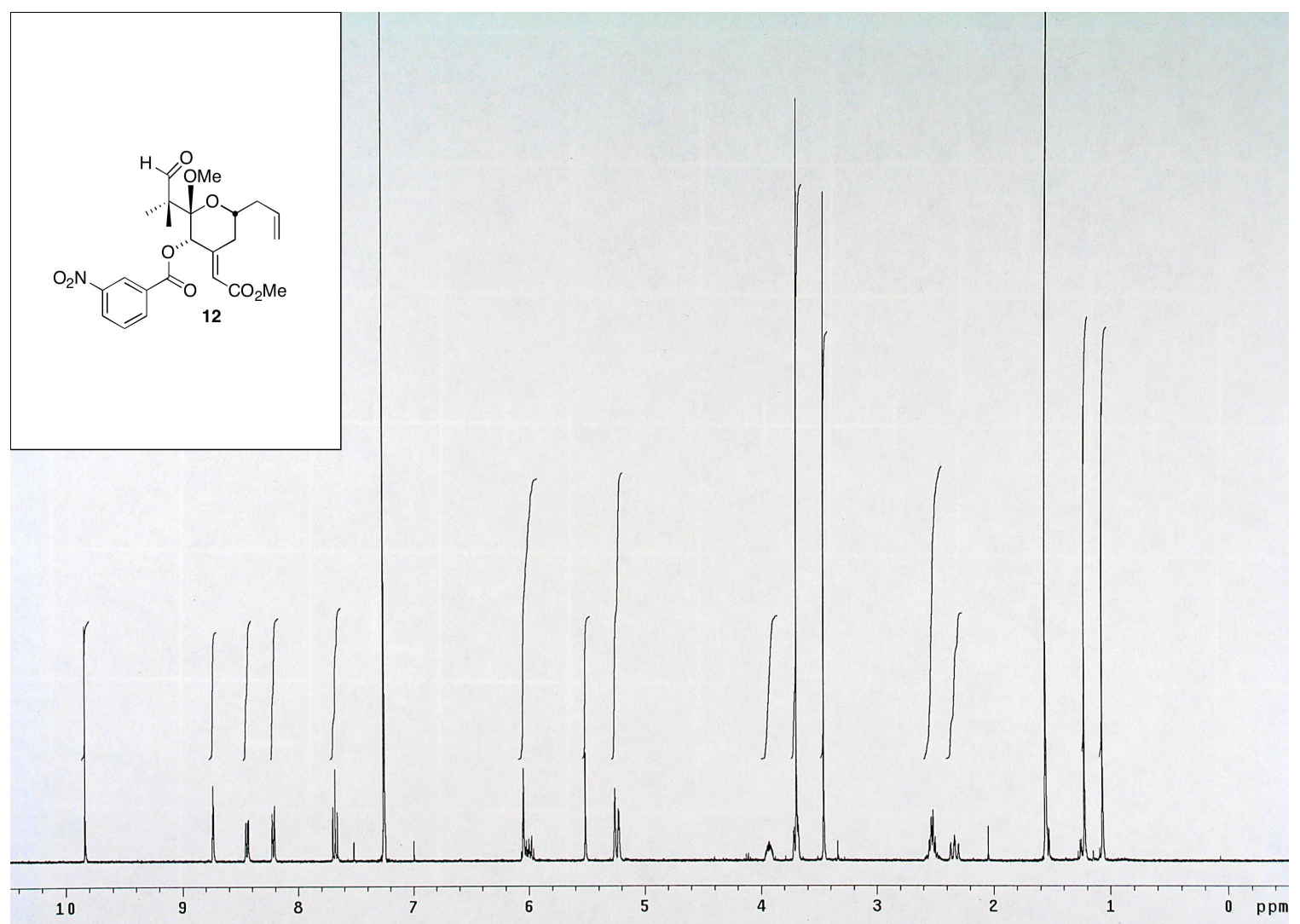




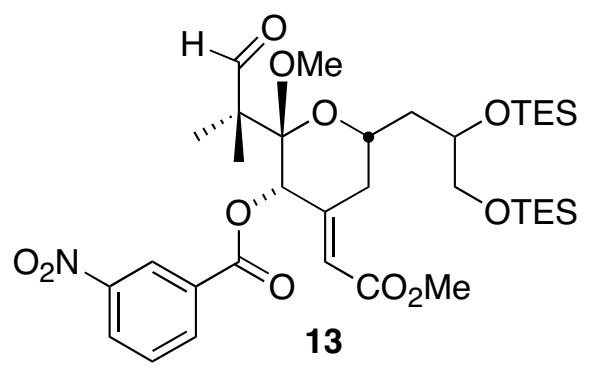

To a rb flask was added (DHQD) $)_{2} \mathrm{PYR}(19.2 \mathrm{mg}), \mathrm{K}_{2} \mathrm{OsO}_{2}(\mathrm{OH})_{4}(3.2 \mathrm{mg}), \mathrm{K}_{3} \mathrm{Fe}(\mathrm{CN})_{6}(2.12 \mathrm{~g}), \mathrm{K}_{2} \mathrm{CO}_{3}(880$ $\mathrm{mg}), t \mathrm{BuOH}(10.8 \mathrm{~mL})$ and $\mathrm{H}_{2} \mathrm{O}(10.8 \mathrm{~mL})$. The resulting mixture was stirred at $\mathrm{rt}$ for $1 \mathrm{~h}$ and then added to a ice cold flask containing $12(724 \mathrm{mg}, 1.57 \mathrm{mmol})$ and the reaction was stirred for $18 \mathrm{~h}$ at $4{ }^{\circ} \mathrm{C}$. The reaction was diluted with $\mathrm{H}_{2} \mathrm{O}(60 \mathrm{~mL})$ and extracted with EtOAc $(3 \times 40 \mathrm{~mL})$. The combined organic layers were dried over $\mathrm{Na}_{2} \mathrm{SO}_{4}$, filtered and concentrated in vacuo to a residue that was used directly in the next step.

The residue from the previous step was dissolved in $\mathrm{CH}_{2} \mathrm{Cl}_{2}(16 \mathrm{~mL})$. To the resulting solution were added imidazole $(285 \mathrm{mg}, 4.20 \mathrm{mmol})$ and TESCl $(527 \mu \mathrm{L}, 3.15 \mathrm{mmol})$. The resulting cloudy solution was stirred for $18 \mathrm{~h}$ at $\mathrm{rt}$ and then diluted with $\mathrm{CH}_{2} \mathrm{Cl}_{2}(35 \mathrm{~mL})$. The mixture was washed with 1:1 $\mathrm{H}_{2} \mathrm{O}$ :satd. aq. $\mathrm{NaHCO}_{3}$ and the resulting organic layer was dried over $\mathrm{Na}_{2} \mathrm{SO}_{4}$, filtered and concentrated in vacuo to a residue that was purified by flash chromatography (silica, 9:1 pet. ether:EtOAc) to yield $695 \mathrm{mg}(61 \%)$ of a clear oil.

$\mathbf{R}_{f}: 0.42$ (silica, 9:1 pentane:EtOAc) - one spot UV and $p$-anisaldehyde

${ }^{1} \mathbf{H}$ NMR: $\left(\mathrm{CDCl}_{3}, 400 \mathrm{MHz}\right) \delta[9.82,9.80(1 \mathrm{H}, \mathrm{s})], 8.77-8.73(1 \mathrm{H}, \mathrm{m}), 8.46-8.41(1 \mathrm{H}, \mathrm{m}), 8.23-8.17(1$ $\mathrm{H}, \mathrm{m}), 7.71-7.64(1 \mathrm{H}, \mathrm{m}),[6.03,6.02(1 \mathrm{H}, \mathrm{s})],[5.62(0.71 \mathrm{H}, \mathrm{s}), 5.59(0.29 \mathrm{H}, \mathrm{s})], 4.20-4.11(1 \mathrm{H}, \mathrm{m})$, [4.10-4.03 $(0.76 \mathrm{H}, \mathrm{m}), 4.03-3.97(0.24 \mathrm{H}, \mathrm{m})], 3.73-3.63(2 \mathrm{H}, \mathrm{m}),[3.69,3.67(3 \mathrm{H}, \mathrm{s})], 3.61-3.49(1 \mathrm{H}$, $\mathrm{m})$, [3.50, $3.48(3 \mathrm{H}, \mathrm{s})], 2.34-2.24(1 \mathrm{H}, \mathrm{m}), 2.10-2.02(1 \mathrm{H}, \mathrm{m})$, [2.00-1.90, 1.78-1.69 (1 H, m)], [1.22, $1.21(3 \mathrm{H}, \mathrm{s})], 1.07(3 \mathrm{H}, \mathrm{s}), 1.02-0.92(18 \mathrm{H}, \mathrm{m}), 0.68-0.56(12 \mathrm{H}, \mathrm{m}) \mathrm{ppm}$. Peaks listed in brackets correspond to diastereomeric peaks.

${ }^{13}$ C NMR: $\left(\mathrm{CDCl}_{3}, 125 \mathrm{MHz}\right) \delta 202.5,165.9,162.4,149.6,148.2,139.4,130.5,129.8,127.9,125.0,119.7$, $102.0,72.4,70.3,69.0,67.2,54.0,51.6,51.2,41.6,32.1,18.7,16.5,6.9,6.7,5.3,4.3 \mathrm{ppm}$. Only major diastereomer listed.

HRMS: $m / z=746.3392\left(\mathrm{M}+\mathrm{Na}^{+}\right)$. Calcd for $\mathrm{C}_{35} \mathrm{H}_{52} \mathrm{NNaO}_{11} \mathrm{Si}_{2} .746 .3368$. 


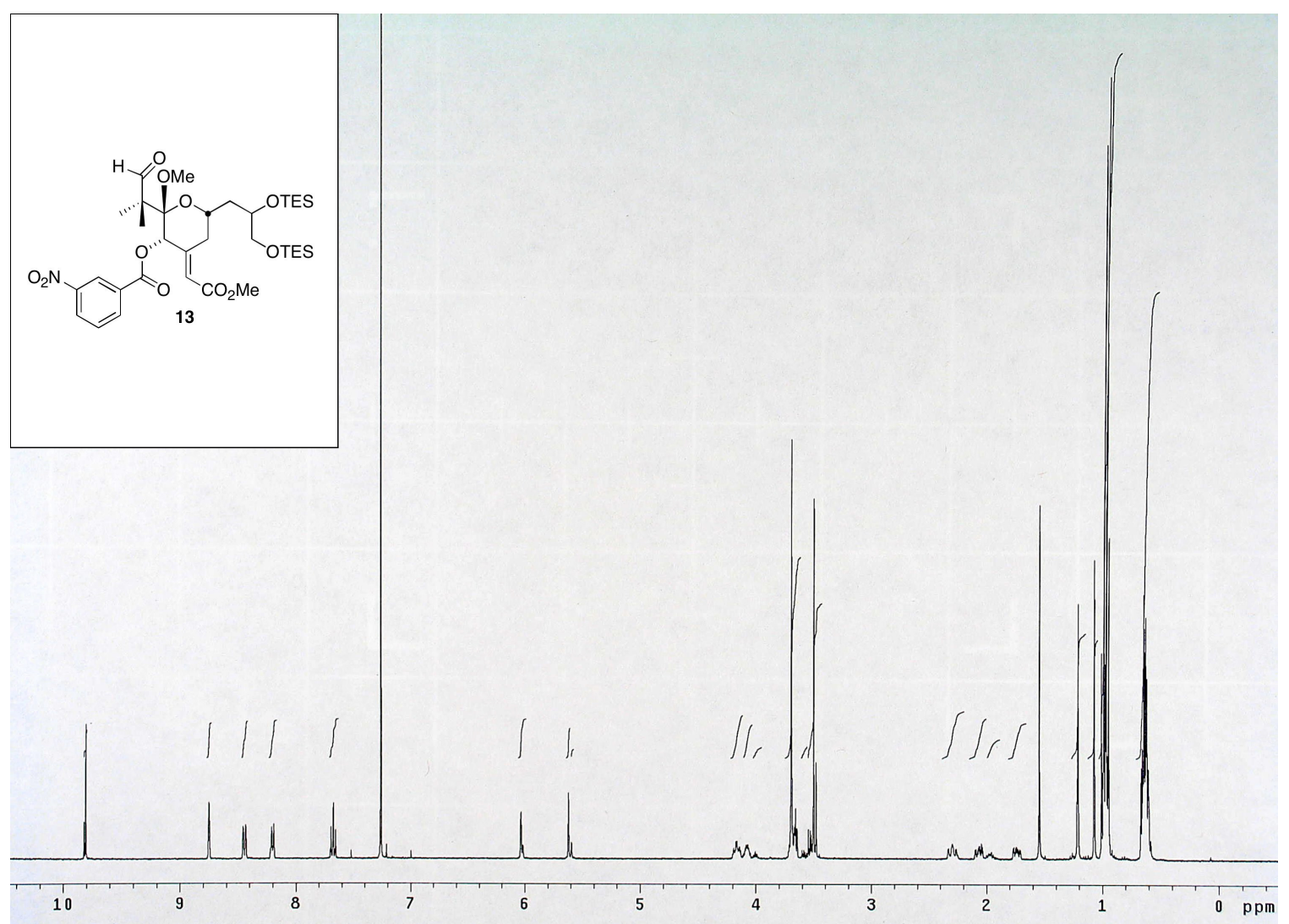




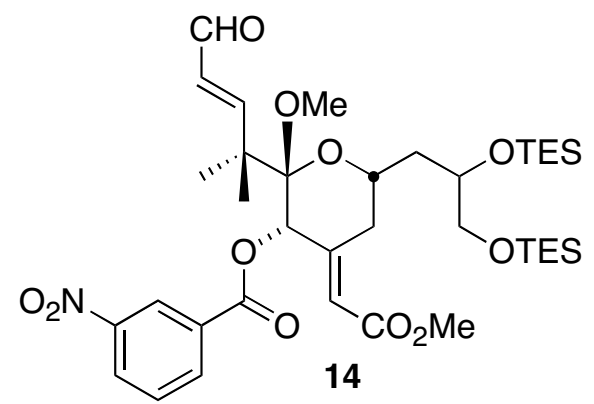

To a flask containing $\mathrm{Et}_{2} \mathrm{O}(25.5 \mathrm{~mL})$ was added $\mathrm{Et}_{2} \mathrm{BOMe}(2.7 \mathrm{~mL}, 20.5 \mathrm{mmol})$ and the resulting solution cooled in an ice bath. A solution of allylmagnesium chloride $(9.37 \mathrm{~mL}, 2.0 \mathrm{M}$ in THF, $18.7 \mathrm{mmol}) \mathrm{was}$ added dropwise over $2 \mathrm{~min}$. The resulting white suspension was stirred in the cold bath for $10 \mathrm{~min}$ and then allowed to settle at rt. In a second flask, a solution of 13 (670 mg, $0.925 \mathrm{mmol})$ was stirred in $\mathrm{Et}_{2} \mathrm{O}$ $(25 \mathrm{~mL})$ in an ice bath. To this solution was added an aliquot $(4.0 \mathrm{~mL})$ of the supernatant from the first flask dropwise over $30 \mathrm{sec}$. The reaction was allowed to stir in the cold bath for $1 \mathrm{~h}$ and another aliquot $(2.0 \mathrm{~mL})$ of the first solution was added. After an additional 10 minutes stirring to the reaction was added 1:1 $\mathrm{H}_{2} \mathrm{O}$ :satd. aq. $\mathrm{NH}_{4} \mathrm{Cl}(30 \mathrm{~mL})$ was added. The resulting mixture was extracted with EtOAc $(3 \mathrm{x} 30 \mathrm{~mL})$ and the combined organic layers were dried over $\mathrm{Na}_{2} \mathrm{SO}_{4}$, filtered, and concentrated in vacuo to an oil which was carried on directly.

The oil from the previous step was dissolved in $\mathrm{CH}_{2} \mathrm{Cl}_{2}(26 \mathrm{~mL})$. To the resulting solution was added DMAP $(677 \mathrm{mg}, 5.55 \mathrm{mmol})$ and $\mathrm{Ac}_{2} \mathrm{O}(261 \mu \mathrm{L}, 2.77 \mathrm{mmol})$. The reaction was stirred overnight at $\mathrm{rt}$ and then poured into 1:1 $\mathrm{H}_{2} \mathrm{O}$ :satd. aq. $\mathrm{NH}_{4} \mathrm{Cl}(80 \mathrm{~mL})$. The resulting organic layer was collected and the aqueous layer was extracted with $\mathrm{CH}_{2} \mathrm{Cl}_{2}(2 \times 30 \mathrm{~mL})$. The combined organic layers were dried over $\mathrm{Na}_{2} \mathrm{SO}_{4}$, filtered, and concentrated under vacuum to a residue that was purified by flash chromatography (silica, 9:1 pentane:EtOAc) to yield $544 \mathrm{mg}$ of a clear oil.

To a solution of of the oil (490 mg) from the previous step in THF (15 mL) was added NMO (355 mg, 3.03 mmol) followed by a solution of $\mathrm{OsO}_{4}$ in $\mathrm{H}_{2} \mathrm{O}(0.75 \mathrm{~mL}, 4 \%)$. The reaction was stirred at $\mathrm{rt}$ for $2.5 \mathrm{~h}$ and additional NMO (80 mg) was added. After an additional hour stirring another aliquot of NMO (80 mg) was added and the stirring continued for $30 \mathrm{~min}$. The reaction was poured into brine $(75 \mathrm{~mL})$ and the resulting mixture extracted with EtOAc( 3 x $30 \mathrm{~mL})$. The combined organic layers were dried over $\mathrm{Na}_{2} \mathrm{SO}_{4}$, filtered, and concentrated under vacuum to a clear oil which was used directly in the next reaction.

The oil from the previous step was redissolved in $\mathrm{C}_{6} \mathrm{H}_{6}(25 \mathrm{~mL})$. To the resulting solution was added $\mathrm{NEt}_{3}$ $(421 \mu \mathrm{L}, 3.0 \mathrm{mmol})$ followed by $\mathrm{Pb}(\mathrm{OAc})_{4}(268 \mathrm{mg}, 0.606 \mathrm{mmol})$. The reaction was stirred for $20 \mathrm{~min}$ at $\mathrm{rt}$ and an additional portion of $\mathrm{Pb}(\mathrm{OAc})_{4}(50 \mathrm{mg})$ was added. After an additional $15 \mathrm{~min}, \mathrm{DBU}(90 \mu \mathrm{L}, 0.61$ mmol) was added. After stirring for 90 min additional DBU $(65 \mu \mathrm{L})$ was added and the reaction stirred 90 min. The reaction mixture was directly purified by flash chromatography (silica, 4:1 pet. ether:EtOAc) to yield $270 \mathrm{mg}(44 \%)$ of a clear oil.

$\mathbf{R}_{f}: 0.24$ (silica, 9:1 pentane:EtOAc) - one spot UV and $p$-anisaldehyde

${ }^{1} \mathbf{H}$ NMR: $\left(\mathrm{CDCl}_{3}, 500 \mathrm{MHz}\right) \delta 9.16(1 \mathrm{H}, \mathrm{d}, J=7.7 \mathrm{~Hz}), 8.70-8.67(1 \mathrm{H}, \mathrm{m}), 8.44-8.40(1 \mathrm{H}, \mathrm{m}), 8.20-8.16$ $(1 \mathrm{H}, \mathrm{m}), 7.66-7.61(1 \mathrm{H}, \mathrm{m}), 7.30(1 \mathrm{H}, \mathrm{d}, J=16.1 \mathrm{~Hz}), 6.02-5.98(1 \mathrm{H}, \mathrm{m}), 5.72(1 \mathrm{H}, \mathrm{dd}, J=16.1,7.7$ $\mathrm{Hz}),[5.68(0.72 \mathrm{H}, \mathrm{s}$, isomer B), $5.66(0.25 \mathrm{H}, \mathrm{s}$, isomer $\boldsymbol{A})], 4.20-4.13(1 \mathrm{H}, \mathrm{m})$, [4.11-4.05 (0.85 H, m, isomer B), 4.05-3.98 (0.27 H, m, isomer A)], 3.69 (3 H, s), 3.70-3.64 (2 H, m), [3.59 (0.32 H, dd, J=10.1, $5.8 \mathrm{~Hz}$, isomer A), $3.53(0.88 \mathrm{H}, \mathrm{dd}, J=10.1,6.4 \mathrm{~Hz}$, isomer B)], [3.46 (2.25 H, s, isomer B), $3.46(0.75 \mathrm{H}$, $\mathrm{s}$, isomer A)], 2.42-2.32 (1 H, m), 2.14-2.27 (1 H, m), 2.05-1.93 (1 H, m), 1.78-1.71 (1 H, m), $1.24(3 \mathrm{H}, \mathrm{s})$, 1.19 (3 H, s), 1.01-0.93 (18 H, m), 0.68-0.57 (12 H, m) ppm.

${ }^{13}$ C NMR: $\left(\mathrm{CDCl}_{3}, 125 \mathrm{MHz}\right) \delta 193.9,166.0,165.9,162.4,150.3,148.3,135.3,130.7,130.0,128.1,126.7$, 124.8, 118.9, [102.7, 102.5], 72.5, 70.3, 69.1, 67.2, 52.0, 51.3, 47.2, 41.8, 32.4, 23.0, 21.3, [7.0, 6.9], [6.8, 6.8], [5.4, 4.9], [4.4, 4.3] ppm.

IR: (thin film) 2954, 2912, 2876, 1724, 1689, 1617, 1537, 1351, 1257, 1128, 1105, $1004 \mathrm{~cm}^{-1}$.

HRMS: $m / z=772.3494\left(\mathrm{M}+\mathrm{Na}^{+}\right)$. Calcd for $\mathrm{C}_{37} \mathrm{H}_{59} \mathrm{NNaO}_{11} \mathrm{Si}_{2} .772 .3524$. 


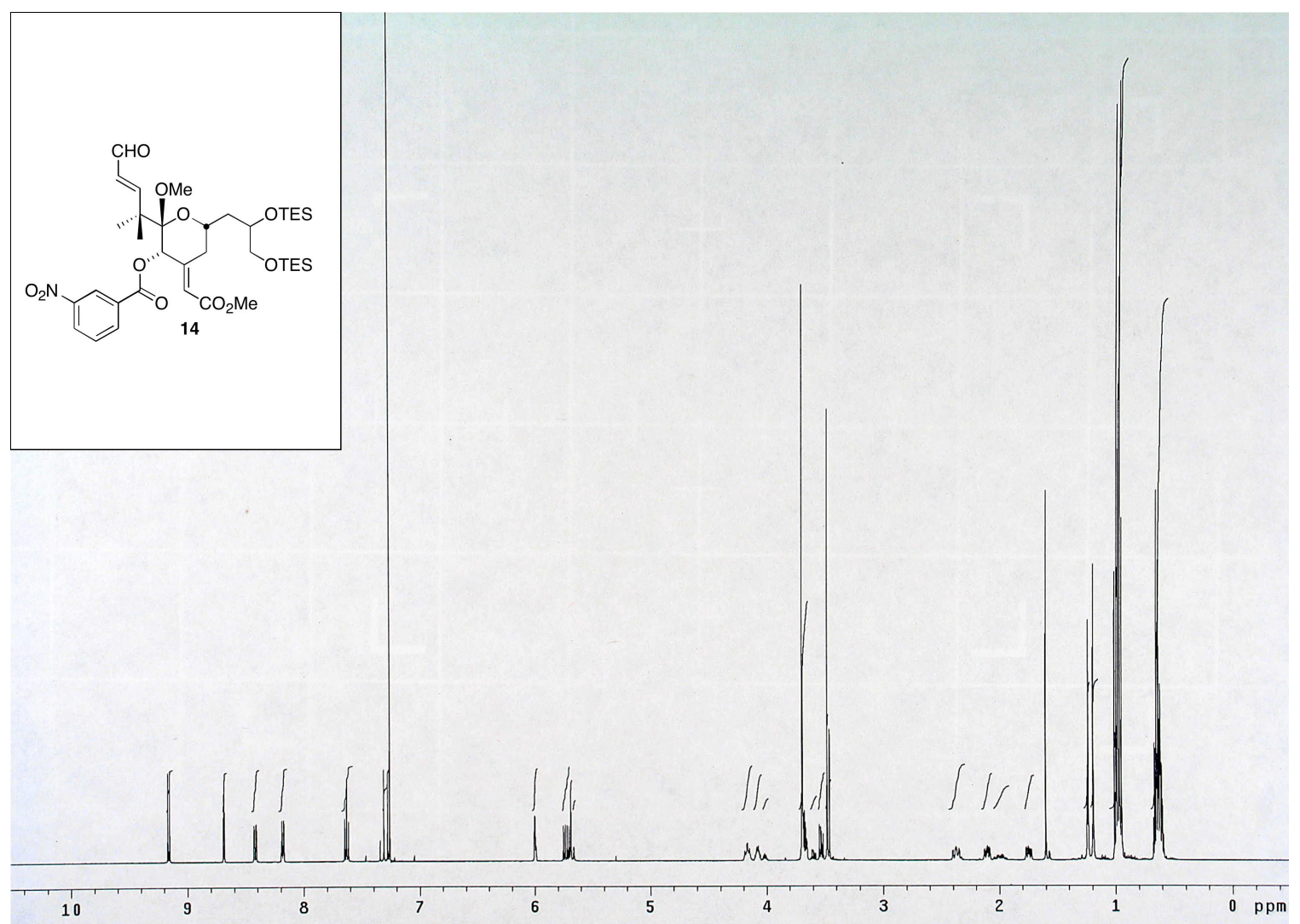




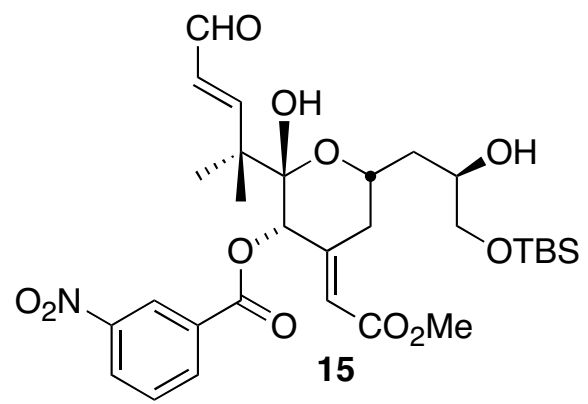

To a solution of $14(135 \mathrm{mg}, 0.18 \mathrm{mmol})$ in $\mathrm{MeCN}(9 \mathrm{~mL})$ and $\mathrm{H}_{2} \mathrm{O}(3.6 \mathrm{~mL})$ was added $p \mathrm{TsOH} \cdot \mathrm{H}_{2} \mathrm{O}(342$ $\mathrm{mg}, 1.8 \mathrm{mmol})$. The resulting solution was stirred at $\mathrm{rt}$ for 4 days and then satd. aq. $\mathrm{NaHCO}_{3}(50 \mathrm{~mL})$ was added. The resulting mixture was extracted with EtOAc $(3 \times 30 \mathrm{~mL})$. The combined organic layers were dried over $\mathrm{Na}_{2} \mathrm{SO}_{4}$, filtered, and concentrated in vacuo to a clear oil which was used directly in the next reaction.

To a solution of the oil from the previous step in $\mathrm{CH}_{2} \mathrm{Cl}_{2}(30 \mathrm{~mL})$ was added imidazole $(55 \mathrm{mg}, 0.81 \mathrm{mmol})$ and TBSCl (41 mg, $0.27 \mathrm{mmol})$. The resulting mixture was stirred at $\mathrm{rt}$ for $3 \mathrm{~h}$. To the reaction was added satd. aq. $\mathrm{NH}_{4} \mathrm{Cl}(30 \mathrm{~mL})$ was added and the organic layer was collected. The aq. layer was extracted with $\mathrm{CH}_{2} \mathrm{Cl}_{2}(3 \times 30 \mathrm{~mL})$ and the combined organic layers were dried over $\mathrm{Na}_{2} \mathrm{SO}_{4}$, filtered, and concentrated in vасио. The resulting residue was purified by flash chromatography (silica, 2:1 pentane:EtOAc) to yield 53 $\mathrm{mg}(47 \%)$ of a clear oil.

$\mathbf{R}_{f}: 0.39$ (silica, 2:1 pentane:EtOAc) - one spot UV and $p$-anisaldehyde

${ }^{1}$ H NMR: $\left(\mathrm{CDCl}_{3}, 500 \mathrm{MHz}\right) \delta 9.25(1 \mathrm{H}, \mathrm{d}, J=7.7 \mathrm{~Hz}), 8.65-8.62(1 \mathrm{H}, \mathrm{m}), 8.43-8.39(1 \mathrm{H}, \mathrm{m}), 8.24-8.20$ $(1 \mathrm{H}, \mathrm{m}), 7.66-7.61(1 \mathrm{H}, \mathrm{m}), 7.33(1 \mathrm{H}, \mathrm{d}, J=16.1 \mathrm{~Hz}), 6.12(1 \mathrm{H}, \mathrm{d}, J=1.8 \mathrm{~Hz}), 5.71(1 \mathrm{H}, \mathrm{dd}, J=16.1$, $7.7 \mathrm{~Hz}), 5.47(1 \mathrm{H}, \mathrm{s}), 4.35-4.27(1 \mathrm{H}, \mathrm{m}), 4.10-4.03(1 \mathrm{H}, \mathrm{m}), 3.82-3.75(2 \mathrm{H}, \mathrm{m}), 3.70(3 \mathrm{H}, \mathrm{s}), 3.55(1 \mathrm{H}$, $\mathrm{dd}, J=10.3,6.0 \mathrm{~Hz}), 3.26(1 \mathrm{H}, \mathrm{s}), 2.19(1 \mathrm{H}$, ddd, $J=13.9,11.6,2.1 \mathrm{~Hz}), 2.15(1 \mathrm{H}, \mathrm{s}), 1.81-1.75(2 \mathrm{H}$, m), $1.19(3 \mathrm{H}, \mathrm{s}), 1.16(3 \mathrm{H}, \mathrm{s}), 0.94(9 \mathrm{H}, \mathrm{s}), 0.12(6 \mathrm{H}, \mathrm{s}) \mathrm{ppm}$.

${ }^{13}$ C NMR: $\left(\mathrm{CDCl}_{3}, 500 \mathrm{MHz}\right) \delta 193.7,166.1,164.9,162.3,149.4,148.2,135.4,130.9,130.0,128.0,127.8$, 124.5, 121.2, 99.8, 73.7, 67.9, 67.1, 67.1, 51.4, 45.8, 39.0, 31.6, 25.9, 23.2, 19.8, 18.4, -5.3 ppm.

IR: (thin film) 3338, 2953, 1702, 1535, 1350, 1291, 1255, 1132, 1086, $984 \mathrm{~cm}^{-1}$.

ES-MS: $m / z=644\left(\mathrm{M}+\mathrm{Na}^{+}\right)$.

HRMS: $m / z=644.2513\left(\mathrm{M}+\mathrm{Na}^{+}\right)$. Calcd for $\mathrm{C}_{30} \mathrm{H}_{43} \mathrm{NNaO}_{11}$ Si. 644.2503.

$[\alpha]_{\mathrm{D}}:-16.5^{\circ}\left(c=1.9, \mathrm{CHCl}_{3}\right)$. 


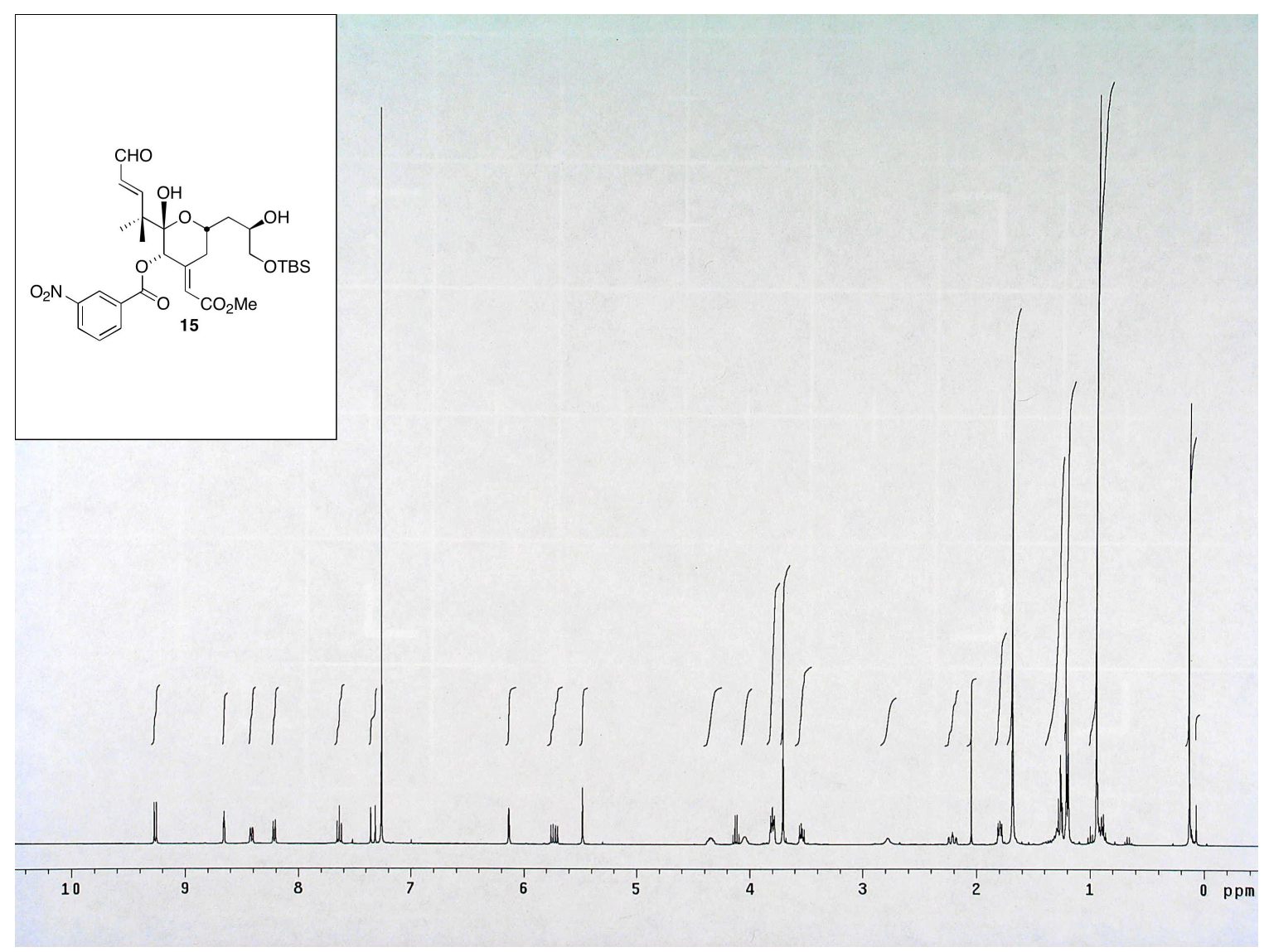




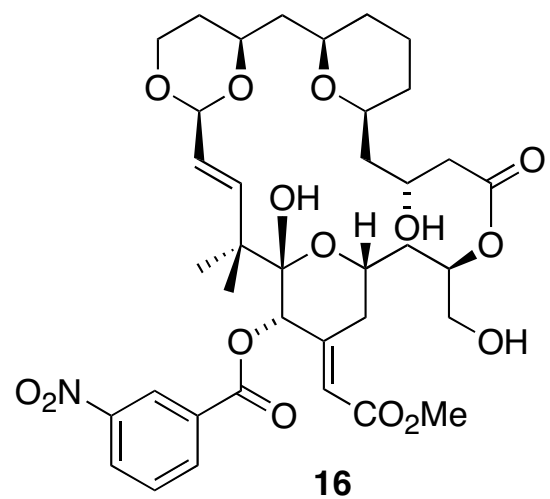

A solution of the spacer domain $(36 \mathrm{mg}, 0.065 \mathrm{mmol})$ in $\mathrm{CH}_{2} \mathrm{Cl}_{2}(2.7 \mathrm{~mL})$ was added to a vial containing 15 (27 mg, $0.043 \mathrm{mmol})$. To the resulting solution was added DIEA (36 $\mu \mathrm{L}, 0.21 \mathrm{mmol}$ ), followed by DMAP (20 mg, $0.16 \mathrm{mmol}$ ) and PyBroP (36 mg, $0.077 \mathrm{mmol}$ ). The reaction was stirred for $1.5 \mathrm{~h}$ and purified directly by flash chromatography (silica, 4:1 $\rightarrow$ 3:1 pentane:EtOAc) to yield $34 \mathrm{mg}$ of a clear oil.

The clear oil from the previous step was dissolved in THF $(14.2 \mathrm{~mL})$ and stirred in a polypropylene tube under a stream of $\mathrm{N}_{2}$. To this solution was added HF.pyr $(3.1 \mathrm{~mL})$ and the resulting solution was stirred at $\mathrm{rt}$ for $5 \mathrm{~h}$. The reaction was poured into a separatory funnel containing satd. aq. $\mathrm{NaHCO}_{3}(50 \mathrm{~mL})$ and the resulting mixture extracted with EtOAc $(4 \times 50 \mathrm{~mL})$. The combined organic layers were dried over $\mathrm{Na}_{2} \mathrm{SO}_{4}$, filtered, and concentrated under vacuum to a clear oil that was purified by flash chromatography (silica, 4:1 EtOAc:pentane) to yield $19 \mathrm{mg}(84 \%)$ of a white solid.

$\mathbf{R}_{f}: 0.47$ (silica, EtOAc) - one spot UV and $p$-anisaldehyde

${ }^{1}$ H NMR: $\left(\mathrm{CDCl}_{3}, 500 \mathrm{MHz}\right) \delta$ 8.86-8.83 $(1 \mathrm{H}, \mathrm{m}), 8.44-8.41(1 \mathrm{H}, \mathrm{m}), 8.36-8.32(1 \mathrm{H}, \mathrm{m})$, 7.69-7.65 $(1 \mathrm{H}$, m), $6.09(1 \mathrm{H}, \mathrm{d}, J=1.9 \mathrm{~Hz}), 6.01(1 \mathrm{H}, \mathrm{d} J=15.7 \mathrm{~Hz}), 5.44(1 \mathrm{H}, \mathrm{s}), 5.43-5.37(2 \mathrm{H}, \mathrm{m}), 5.26(1 \mathrm{H}, \mathrm{s})$, $5.05(1 \mathrm{H}, \mathrm{d}, J=7.4 \mathrm{~Hz}), 4.50(1 \mathrm{H}, \mathrm{d}, J=11.8), 4.25-4.18(1 \mathrm{H}, \mathrm{m}), 4.15(1 \mathrm{H}, \mathrm{tt}, J=11.4,2.2 \mathrm{~Hz}), 4.07(1$ $\mathrm{H}, \mathrm{dd}, J=11.4,4.3 \mathrm{~Hz}), 3.95-3.84(3 \mathrm{H}, \mathrm{m}), 3.76(1 \mathrm{H}, \mathrm{dd}, J=14.0,2.1 \mathrm{~Hz}), 3.71(1 \mathrm{H}, \mathrm{dd}, J=12.0,5.7$ $\mathrm{Hz}), 3.68(3 \mathrm{H}, \mathrm{s}), 3.54(1 \mathrm{H}, \mathrm{t}, J=11.0 \mathrm{~Hz}), 3.47(1 \mathrm{H}, \mathrm{t}, J=11.1 \mathrm{~Hz}), 2.57-2.53(2 \mathrm{H}, \mathrm{m}), 2.15-1.97(3 \mathrm{H}$, m), 1.92-1.72 (4 H, m), 1.66-1.43 (5 H, m), 1.36-1.33 (1 H, m), 1.32-1.21 (2 H, m), $1.17(3 \mathrm{H}, \mathrm{s}), 1.06$ (3 H, s) $\mathrm{ppm}$.

${ }^{13}$ C NMR: $\left(\mathrm{CDCl}_{3}, 125 \mathrm{MHz}\right) \delta 172.5,166.7,162.7,150.7,148.4,142.1,135.4,131.6,129.8,127.7,126.0$, $124.8,120.6,102.2,99.0,78.7,76.0,75.8,75.4,71.5,68.6,66.3,65.6,64.6,51.2,45.0,42.9,42.5,39.9$, $36.0,32.3,31.4,31.3,31.2,24.5,23.0,19.5 \mathrm{ppm}$.

ES-MS: $m / z=770\left(\mathrm{M}+\mathrm{Na}^{+}\right)$.

HRMS: $m / z=770.3021\left(\mathrm{M}+\mathrm{Na}^{+}\right)$. Calcd for $\mathrm{C}_{37} \mathrm{H}_{49} \mathrm{NNaO}_{13} \cdot 770.3000$.

$[\alpha]_{\mathrm{D}}:-16.5^{\circ}\left(c=1.9, \mathrm{CHCl}_{3}\right)$. 


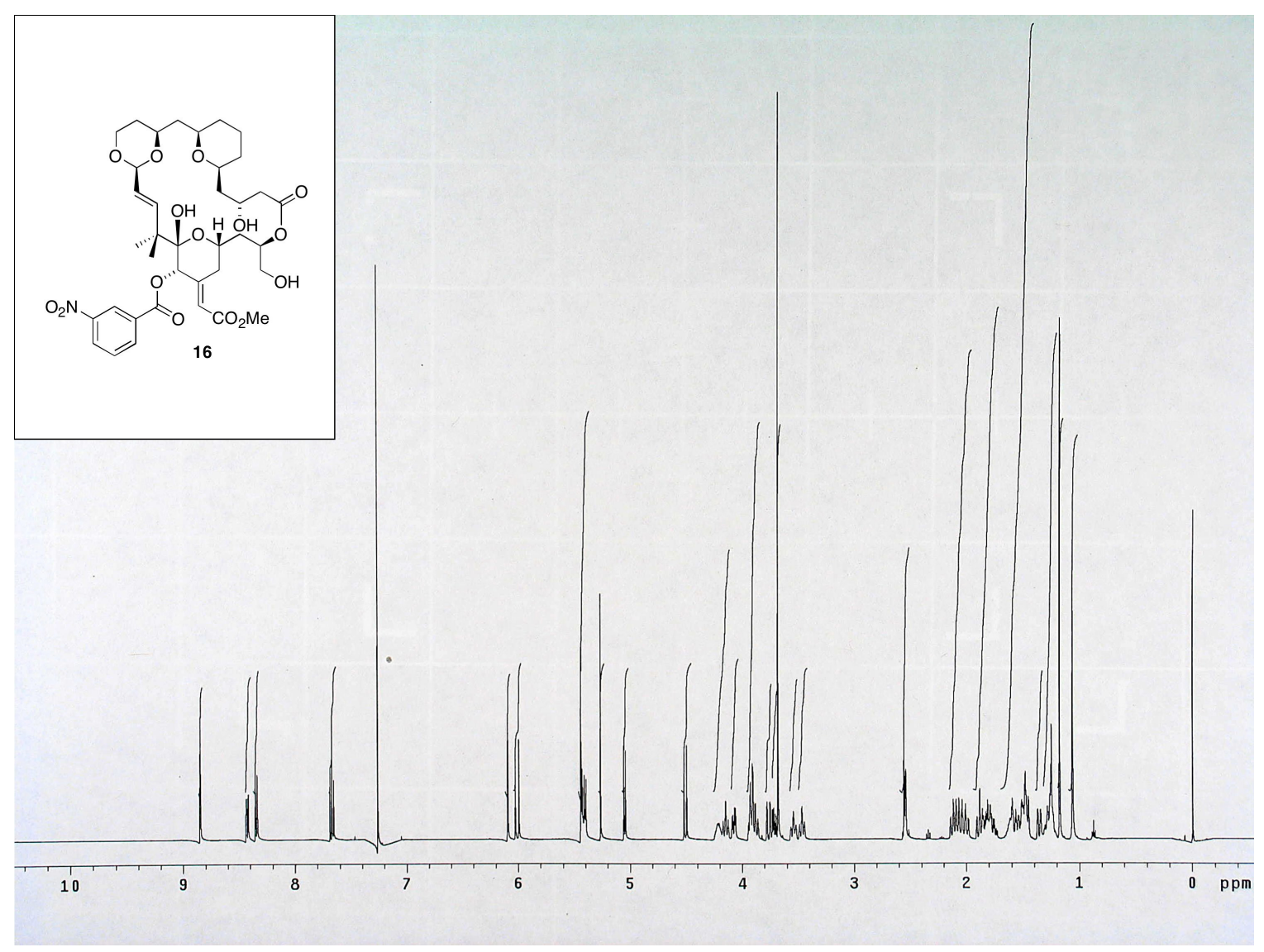




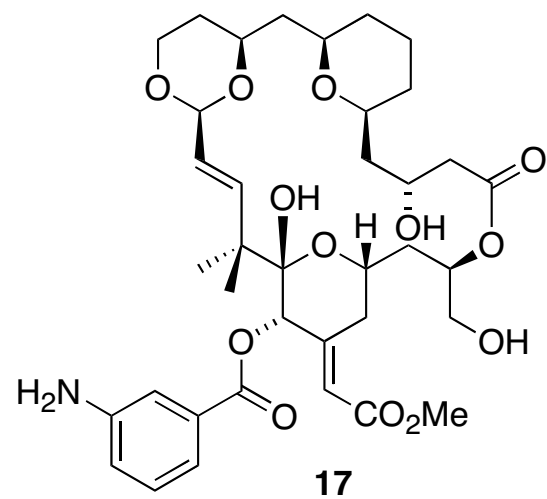

To a vial containing $16(19 \mathrm{mg}, 0.025 \mathrm{mmol})$ was added 10\% Pd/C (2 mg) followed by EtOAc $(5 \mathrm{~mL})$. The reaction was put under an atmosphere of $\mathrm{H}_{2}$ and stirred at $\mathrm{rt}$ for $9 \mathrm{~h}$. The resulting mixture was filtered through celite and concentrated under vacuum to $19 \mathrm{mg}(100 \%)$ of a white solid.

$\mathbf{R}_{f}: 0.44$ (silica, EtOAc) - one spot UV and $p$-anisaldehyde

${ }^{1}$ H NMR: $\left(\mathrm{CDCl}_{3}, 400 \mathrm{MHz}\right) \delta$ 7.45-7.41 (1 H, m), 7.35-7.32 (1 H, m), 7.25-7.19 (1 H, m), 6.90-6.86 (1 H, m), $6.07(1 \mathrm{H}, \mathrm{d}, J=1.8 \mathrm{~Hz}), 6.01(1 \mathrm{H}, \mathrm{d}, J=16.0 \mathrm{~Hz}), 5.45-5.36(2 \mathrm{H}, \mathrm{m}), 5.38(1 \mathrm{H}, \mathrm{s}), 5.17(1 \mathrm{H}, \mathrm{s})$, $5.03(1 \mathrm{H}, \mathrm{d}, J=7.5 \mathrm{~Hz}), 4.49(1 \mathrm{H}, \mathrm{d}, J=11.7 \mathrm{~Hz}), 4.26-4.16(1 \mathrm{H}, \mathrm{m}), 4.16-4.04(2 \mathrm{H}, \mathrm{m}), 3.95-3.83(3$ $\mathrm{H}, \mathrm{m}), 3.76-3.64(2 \mathrm{H}, \mathrm{m}), 3.66$ (3 H, s), 3.58-3.49 (1 H, m), 3.49-3.42 (1 H, m), 2.56-2.52 (2 H, m), 2.172.08 (1 H, m), 2.18-1.95 (2 H, m), 1.93-1.72 (4 H, m), 1.62-1.42 (5 H, m), 1.40-1.20 (5 H, m), 1.19 (3 H, s), $1.05(3 \mathrm{H}, \mathrm{s}) \mathrm{ppm}$.

${ }^{13}$ C NMR: $\left(\mathrm{CDCl}_{3}, 100 \mathrm{MHz}\right) \delta 172.9,167.2,165.0,151.8,146.5,142.7,131.0,129.7,125.9,120.7,120.2$, $116.3,102.6,99.4,78.9,76.2,76.0,74.6,71.9,68.8,66.5,66.0,64.8,51.3,45.3,43.1,42.7,40.2,36.3$, 32.6, 31.6, 31.6, 31.5, 29.9, 24.8, 23.2, $19.6 \mathrm{ppm}$.

IR: (thin film) 3452, 3380, 2920, 2849, 1719, 1643, 1325, 1295, 1228, 1137, $1104 \mathrm{~cm}^{-1}$.

ES-MS: $m / z=740\left(\mathrm{M}+\mathrm{Na}^{+}\right)$.

HRMS: $m / z=740.3249\left(\mathrm{M}+\mathrm{Na}^{+}\right)$. Calcd for $\mathrm{C}_{37} \mathrm{H}_{51} \mathrm{NNaO}_{13} \cdot 740.3258$.

$[\alpha]_{\mathrm{D}}:-23.2^{\circ}\left(c=0.4, \mathrm{CH}_{2} \mathrm{Cl}_{2}\right)$.

MP: $165^{\circ} \mathrm{C}$, decomp. 


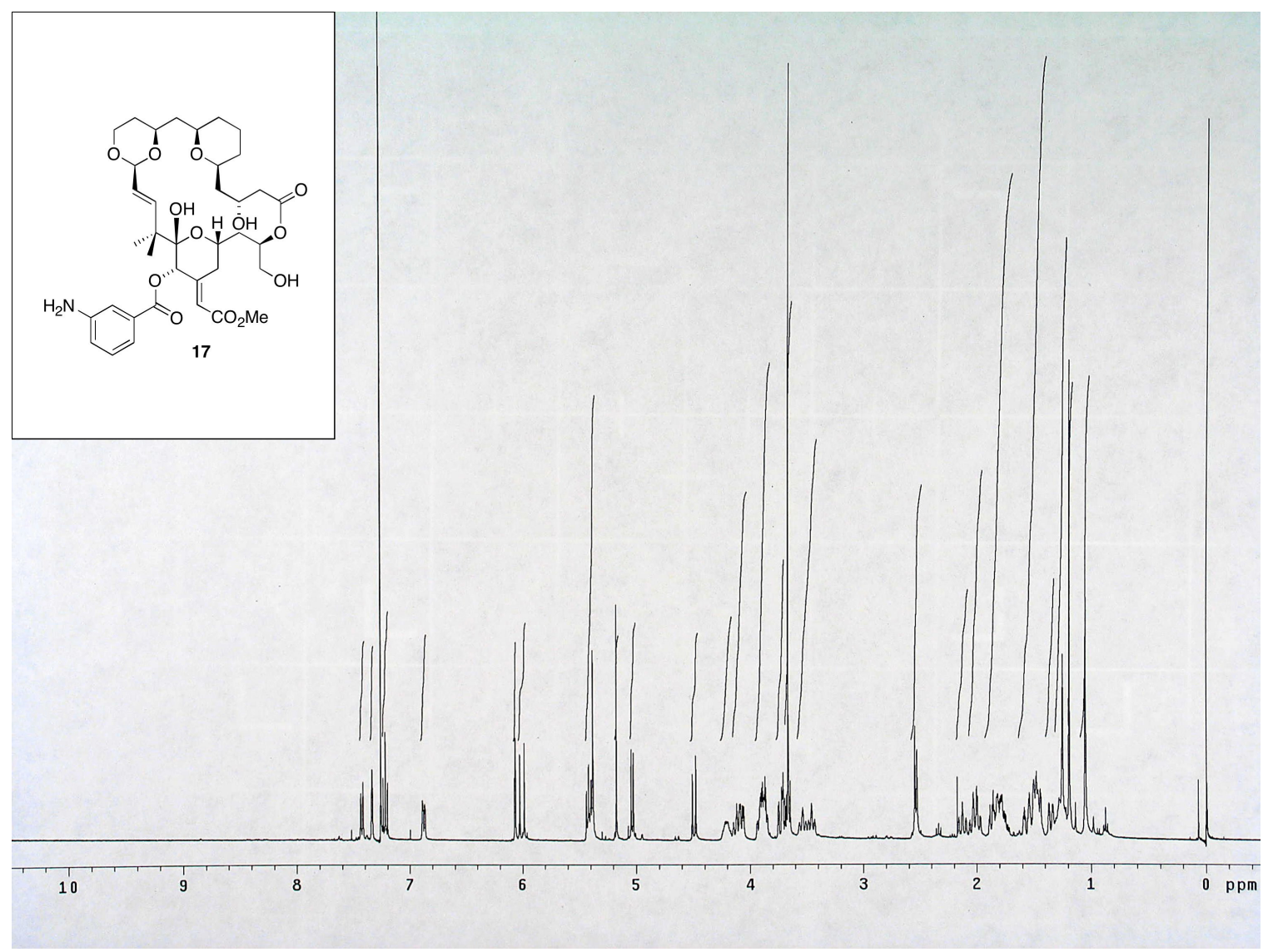

